\title{
Mary Mitchell Slessor (1848 - 1915) and Her Impact on the Missionary Enterprise in the Cross River Region
}

\author{
Augustine Onah Odey, Gregory Ajima Onah
}

Abstract

Born December 2, 1848 in Gilcomston, Aberdeen, Scotland, Mary Mitchell Slessor, a five foot, red haired Scottish Missionary who pioneered her way into the jungles of Africa was undoubtedly one of the most outstanding missionaries who made tremendous contributions to evangelism, charity work, educational and healthcare services and publicized Nigeria in the map of the world. She faced many challenges living with the villagers, and at times, even had to be a peacemaker between tribesmen. Her work and strong personality allowed her to be trusted and accepted by the locals while spreading Christianity in Nigeria, promoting women's rights, rescuing unwanted children, protecting native children and died on 13 January, 1915 (aged 66) at Use Ikot Oku, Calabar, Nigeria. Beyond contribution to knowledge this brief work is therefore a legacy of Mary Mitchell Slessor's contributions to the evangelization of Nigeria and Church History.

Key Words: Calabar, Christianity, Cross River Region, Mary Slessor, Missionary Enterprise, Nigeria, Twins

\section{Introduction}

Few works exist on the part played in the evangelization of Nigeria by Nigerian descent and church founders (Ferguson, 1978) and as a result very little is known about them except for very few lucky ones like Samuel Ajayi Crowther (1806 - 1891) and Essien Essien Ukpabio, the first Efik Minister ordained in October, 1853. By her colossal and myth-breaking contributions, twins and their mothers are celebrated in Nigeria. There could therefore, not be a better time to historicize our heroine, Mary M. Slessor than on her centenary. Who is Mary Slessor and how has she impacted Nigerian missionary enterprise?

Birth and Early Life of Mary Slessor

Mary Slessor was born on $2^{\text {nd }}$ December, 1848 in Gilcomston, Aberdeen, Scotland in a poor working-class family. She was the second of seven children of Robert and Mary Slessor. Her father, Robert, originally from Buchan, was a shoemaker by trade. Mary M. Slessor prayed with her mother, Mary Slessor, continually for God's provision and protection. She became a Christian at a young age. Not well educated but learned to read, and loved reading the Bible.

In 1859 , at the age of eleven, the family moved to Dundee in search of work. Here, Mary Mitchell Slessor gathered boys and girls to attend Sunday school in Dundee, Scotland. Her father, Robert Slessor was an alcoholic and unable to keep up shoemaking, took a job as a labourer in a mill. Her mother, a skilled weaver, also went to work in the mills. At the age of eleven, Mary Mitchell Slessor began work as a "half-timer" in the Baxter Brothers' Mill, meaning she spent half of her day at a school provided by the mill owners and the other half working for the company in her effort to enable her help or assist her family. This is a great lesson for many Nigerian youths who stay out of school on ground that they have no one to cater for their studies (Kingsley, 1988). 
The Slessors lived in the slums of

Dundee. Before long Mary's father, Robert, died of pneumonia, and both her brothers also died, leaving behind only Mary, her mother and two sisters. By age fourteen (1862), Mary had become a skilled jute worker, working from 6.00am to $6.00 \mathrm{pm}$ with just an hour for breakfast and lunch (Lingston, 1927).

Her mother was a devout Presbyterian who read each issue of the Missionary Record, a monthly magazine published by the United Presbyterian Church (later the United Free Church of Scotland) to inform members of missionary activities and needs. Slessor developed an interest in religion and when a mission was instituted in Quarry Pend (close by the Wishart Church), she wanted to teach. In 1875, Slessor was twenty-seven when she heard about David Livingstone (the greatest of the European explorers, a Scottish missionary who traversed vast barren wastes and jungles from the Cape of Good Hope as far north as Lake Tanganyika and from the Atlantic to the Indian Ocean. He discovered Victorian falls and the Zambezi River. He began his series of explorations in 1853. He died in 1873. The natives called him, "The very great doctor", Wallbank, Taylor and Bailkey, 1971:647) the famous missionary and explorer, had died and decided she wanted to follow his footsteps.

It was however from Mr. Thomson, as architect from Glasgow, who had earlier explored the rivers and hills of West African Coast that Mary M. Slessor learned most about the strange country to which she was to spend most of her life.
Early Missionary Career of Mary Mitchell Slessor

The earliest known Christian mission to Nigeria was the Portuguese Roman Catholic Mission which came to Benin in the sixteenth century at the invitation of Oba Esigie, King of Benin. Later in the seventeenth century a more successful mission by the Sacra Congregazione de Propaganda Fide, established in Rome in 1622, came to Warri. It is possible that both the Benin and Warri missions diffused into the Niger Delta. By the beginning of the nineteenth century, however, nothing seems to have survived of these earlier missions. By some accidents of history also, the Niger Delta was not to be considered in the early nineteenth century European missionary strategy, for it had become notorious, especially among nineteenth century travellers for unhealthiness and savagery. Besides, at the inception of the missionary movements, especially those from Britain, part of the major objectives had been to reach the Hinterlands to convert the slave dealers in the hope that converting them to Christianity, in addition to introducing "civilization" and commerce, would deal a devastating blow to the slave trade. Since the Niger Delta was largely an exporter rather than a producer of the slaves, it, iso racto, became ignored. Agriculturally, the Niger Delta was also not considered important at the time when the agriculture productivity of a place enhanced its importance. Thus, the Niger could not even attract European commercial interests (Tasie, 1978:323-332).

On April 10, 1846 Hope Waddell and his missionary team of the United Presbyterian Church of Scotland arrived Calabar. In October 1853, seven years after Hope Waddell's arrival in 
ISSN 2229-5518

Calabar, Essien Essien Ukpabio, the first baptized covert was received into the Church was King Eyo of Creek Town. Eventually, Mary Mitchell Slessor applied to the United Presbyterian Church's Foreign Mission Board. After training in Edinburgh, the set sail in the steamer Ethiopia in Liverpool docks and waved good-bye to two companions from Dundee who had gone to see her off on an autumn morning on August 1876, and arrived at her destination in Calabar (West Africa) just over a month later (Wikipedia, 2015).

In 1876, on arrival in Calabar, Mary Slessor at 28 years of age, red haired with bright blue eyes (Hardage, 2010), was first assigned to the Calabar region in the land of Efik people. She was warned that the Efik people believed in traditional West African religion and had superstitions in relation to women giving birth to twins. Slessor lived in the missionary compound for three years, working first in the missions in Old Town and Creek Town. Ayandele (1991: 74) reported that in 1873 the part of Duke Town in Old Calabar known as Henshaw Town was the most responsive to missionary teaching and accordingly formed the Young Calabar who on the surface had a purely social and religious programme which consisted of casting of tribal religion, en masse acceptance of Christianity, and adoption of European clothing. He added that in a society like the Efik's where religion could not be separated from politics, such programme implied political independence of Duke Town. Moreover, the missionaries encouraged Henshaw Town's aspirations and one of them took part in the coronation of an independent King for the "town". However, Duke Town authorities, the diehard "pagans", sought to nullify all this by using Ekpo, a kind of freemasonry with "pagan" rituals.

Mary Slessor wanted to go deeper into Calabar, but she contracted malaria and was forced to return to Scotland to recover. She left Calabar for Dundee in 1879 (aged 30). After sixteen months in Scotland, Slessor returned to Calabar, but not to the same compound. Her new assignment was three miles farther into Calabar, in Old Town. Since Slessor assigned a large portion of her salary to support her mother and sisters in Scotland. She economized by learning to eat the native food. Mary Slessor adopted four children: Jean, Alice, Maggie and May.

\section{Mary Mitchell Slessor among the Okoyong and Efik}

In Augustine 1888, Slessor travelled north to Okoyong, an area where previous male missionaries had been killed. She thought that her teachings, and the fact that she was a woman, would be less threatening to unreached tribes. For fifteen years, Slessor lived with Okoyong and Efik people. She learned to speak Efik, the language of the people, and made close personal friendships whenever she went, becoming known for her pragmatism and humour. Slessor lived a simple life in a traditional house with Efiks. Her insistence on lone stations, often lead Slessor into conflict with the authorities and gained her a reputation for eccentricity.

In 1902, among the Okoyong people, eleven youngsters threatened her with weapon but Mary never budged. She thus gained respect of the leader of the gang and Mary invited them all to join in with the other kids to attend Sunday 
ISSN 2229-5518

school. They were baptized including seven of her adopted children.

\section{How Mary Mitchell Slessor Imparted Nigerian Church History}

Issues Mary Slessor confronted as a young missionary included the lack of Western education, as well as widespread human sacrifice at the death of a village elder or head, which, it was believed, required servants and retainers to accompany him to the next world.

The birth of twins was considered a particularly evil course. Indigenes or Africans feared that the father of one of the infants was an evil spirit, and that the mother had been guilty of a great $\sin$. Unable to determine which twin was fathered by the evil spirit, the people often abandoned both babies in the bush. Slessor adopted every child she found abandoned and sent out twin's missioners to find protect and care for them at the Mission House. Some mission compounds were alive with babies. It was reported that Mary Slessor once saved a pair of twins, a boy and a girl, but the boy did not survive. Mary Slessor took the girl as her daughter and called her Janie. This Janie she took with her to Scotland on yet another health furlough raised her up as a Christian (White, 2010). Many childless couples or single parents now have smiles put on their faces by popularizing Mary Slessor's adoption of babies' legacy. Many celebrated twins would have been killed but for Mary Slessor's legacy.

Mary Slessor was a driving force behind the establishment of the Hope Waddell Training Institution in Calabar (opened in 1895), which provided practical vocational training to Efiks.

The superstitions threat against twins was not only in Calabar, but also spread to Arochukwu on the far west of Calabar. There was an Elementary School named in honour of Mary Slessor in Arochukwu. Her exploits were heralded in Britain and she became known as the "white queen of Okoyong". She did not focus on evangelism, but rather on settling disciples, encouraging trade, establishing social changes and introducing Western or formal education.

In 1892, Mary Slessor became viceconsul in Okoyong, presiding over the customary or native court. In 1905, she was named vice-present of Ikot Obong native court. In 1913 she was awarded the Order of St. John of Jeruselem. Slessor's work in Okoyong earned her the Efik nickname of Obonganwan Okoyong (Queen of Okoyong). This name is still used commonly to refer to her and many other women in Akwa Ibom State and the Southern Senatorial District of Cross River State. Several memorials in and around the Efik provinces of Calabar and Okoyong testify to the value placed on her work. Some of these include:

- Mary Slessor Road in Calabar from Calabar Road to UNICAL.

- Mary Slessor Roundabout at Marian Hill, Calabar.

- Mary Slessor Church, Port Harcourt.

- Statues of her (usually carrying twins) at various locations in Calabar.

- Main-belt asteroid 4793 Slessor (1988 RR4) named after her to mark the centenary celebrations on $13^{\text {th }}$ January, 2015 (https://www.facebook.com/achimo taschool). 
ISSN 2229-5518

Mary Mitchell Slessor was one of the greatest women of her generation. The British described her as a "tornacto". She was nicknamed "Carrott", because of her flaming hair. She was also nicknamed "Fire" because of her flaming anger or temper. She was a gentle, sensitive and loving Christian. In 1907, she established a mission at Arochukwu, though she remained or stayed at Ikot Obong. Obutong, Creek Town, Okoyong, Eniong, Itu, Use, Ikpe and Ediene, all fell to her misionarying influence. At Use Ikot $\mathrm{Oku}$, she established a centre for mothers of twins and other distressed women. In 1903, with the aim of passing on to Arochukwu area, she visited Itu (Onah, 2013).

A plot of land was donated to her by the chiefs of Okoyong in 1890 for the building of her house. A missionary carpenter, Mr Owen, built a house for her in 1899. All the materials used in the construction of her one-storeyed building were imported from England.

She was appointed a British Vice Consul in 1892 by the Consul General of Niger-Coast Protectorate, Major (later Sir) Claude Macdonald. She pierced through the then unfriendly EfikIbibio ethnic groups around modern Itu. Africans call her "Mother of All People". She trained herself to live and think like an African. She spoke the local languages fluently and walked bare-footed. She is not only a model but also a mentor to many men and women, clergy and lay people. She saved hundreds of twins out of the bush, where they had been left either to starve to death or be eaten by animals. She helped heal the sick and stopped the practice of determining guilt by making the suspects drink poison.

\section{Death}

For the last four decades of her life, Mary Slessor suffered intermittent fevers from the malaria she contracted during her first station to Calabar and had to travel to Scotland thrice for treatment. During her third mission to Calabar her mother and sister died and so found a sense of independence. With these dead she concluded that "heaven is now nearer to me than Britain and no one will worry about me if i go up country" (Onah, 2014).

The fever eventually weakened Mary M. Slessor to the point where she could no longer walk long distances in the rainforest, but had to be pushed along in a hand-cart. In early January, 1915, while at her remote station near Use Ikot $\mathrm{Oku}$, she suffered a particularly severe fever. Mary Mitchell Slessor died on $13^{\text {th }}$ January, 1915 (Onah, 2014). Her body was transported down the Cross River to Duke Town for the colonial equivalent of a state funeral. A Union Jack covered her coffin. Attendees included the Provincial Commissioner, along with other senior British officials in full uniform. Flags at government buildings were flown at half mast. Nigeria's Governor-General Sir Frederick Lugard, telegraphed his "deepest regret" and condolences from Lagos and published a warm tribute in the Government Gazette (Proctor, 2012).

\section{Conclusion}

Sixty-six-year-old Mary Mitchell Slessor died in Use Ikot Oku, Nigeria. A petite redhead everybody's mother from the slums of Dundee, Scotland, becomes a role model for others, even 
ISSN 2229-5518

today. She has wielded such influence in the land

known to her compatriots as the white man's grave. She perfectly fits into the British Empire's plan to "civilize" Nigeria. Our foregoing discussion and other studies on Mary Slessor's life reveal certain factors leading to missionary fervour, combined with a large measure of down-to-earth common sense. Through the trying circumstances of her youth, she learned to face and overcome difficult situations in ways that often challenges the mission methods and attitudes of her era. Mary Slessor's stubborn drive to open new territory to education and the presentation of the gospel message stands as a prime example of what Ogbu U. Kalu, Nigerian Church historian and professor of World Christianity and Mission at McCormick Theological Seminary, Chicago, refers to as "a broader view of the style and vision of the missionary enterprise" (Kalu, 2002). Mary Slessor's vision was much broader and more activist than her compatriots could imagine (Walls, 1996:172).

Mary Slessor demonstrated her social activism in a number of ways: her persistent rescue of twins and orphans, in some cases adopting and raising the children as her own; her determination to make life better for women in general, especially in setting up vocational training schools for them; her use of the "each one teach one" principle later espoused by Frank Laubach and other modern literacy, proponents (she would send a couple of boys who had learned to read into a village that had invited her to come, and there she would teach them not only reading but also what they knew of the Bible); and her participation in settling disputes, whether as an agent of the British government or on an informal, personal basis. She brought a semblance of order to communities in a time of social and political upheaval (Kalu, 2002).

Slessor represents a genre of missionary presence which rejected the social and spatial boundaries created by the "ark syndrome" in missionary attitude. In Calabar she was a catalyst that challenged the mission to change emphasis, to become a sending body rather than a mostly stationary body, a practice the mission's converts had been urging for some years. She garnered support from younger mission colleagues, in addition to being admired by British colonial personnel and the people of the districts where she lived and worked (Buchan, 1981: 25).

Mary Slessor's importance in the history of the development of the Church in Africa cannot be denied. She is remembered - by some, venerated - in both Scotland and South-Eastern Nigeria. In 2000 she was chosen as one of the millennium persons of Calabar, the place she began her witness for Christ. She is honoured in the area with statues, each a likeness of Mary Slessor holding twin babies. A hospital and schools are named for her. In Scotland a tenpound note bears her picture. Queen Elizabeth laid a wreath at her grave in Calabar in 1956. The museum in Dundee displays stained glass windows that depict events from her life. Mary Slessor herself would have shunned such goingson. Regardless, she left a trail of churches and schools, a host of people who admired her deeply and many who still do. She is the harbinger of Women Liberation and Child Rights Law. 


\section{References}

Ayandele, E. A. (1966, Fifth Impression, 1991). The Missionary Impact on Modern Nigeria, 1842 - 1914: A Political and Social Analysis, London: Longman Group Ltd.

Buchan, James (1981). The Expendable Mary Slessor, New York: Seabury Press.

Hardage, Jeannette (2010). Mary Slessor: Mother of All Peoples, New Rochelle, New York: Holy Trinity.

John Ferguson (1978). Some Nigerian Church Founders. Ibadan: Daystar Press.

Kingsley, Mary H. (1988, Originally published 1897). Travels in West Africa, Boston: Beacon Press.

Lingstone, W. P. (1927). Mary Slessor of Calabar, Pioneer Missonary, London: Hodder \& Stoughton.

Ogbu, U. Kalu (February 25, 2002). A paper presented at McGormick Theological Seminary, Chicago.

Onah, A. Odey (2014). "Issues in Nigerian and African Church History, 1849 - 2009", European Journal of Scientific Research, EJSR, Vol. 123, Issue 3.

Onah, A. Odey (October, 2013). "ProphetEvangelist Garrick Sokari Idaketima Braide: The First Revivalist in Nigeria (1882- 1918), International Journal of Humanities and Social Science, IJHSS, Vol. 3, No. 17.

Proctor, J. H. (2012). Serving God and the Empire: Mary Slessor in South-Eastern Nigeria, 1876 - 1915, Drill, 45 - 61.

Slessor, Mary, $1848 \quad$ - $\quad 1915$, https://www.facebook.com/achimotasch ool/posts/ 1015203085256741.

Tasie, G. O. M. (1978). "The Church in the Niger Delta", Christianity in West Africa: The Nigerian Story, Ibadan: Daystar Press.

Wallbank, I. W., Tayolor, A. M. \& Bailkey, N. M. (1971). Civilization: Past and Present,
Glenview, Illinois: Scott, Foreman and Company.

Walls, Andrew F. (1996). The Missionary Movement in Christian History: Studies in the Transmission of Faith, Maryknoll, New York: Orbis Books.

White, Donna (29 $9^{\text {th }}$ August, 2010). "Red-hot designers hail Scots missionary for inspiring African style". The Daily Record. Retrieved 2011 - $09-06$.

Wikipedia (2015). The free Encyclopaedia.

Augustine O. Odey is of the Department of Religious and Cultural Studies,

University of Uyo, P.M.B. 1017, Uyo

Nigeria, West Africa

onah.odey@yahoo.com

Gregory A. Onah, is of the Department of Religious and Cultural Studies

University of Calabar, P.M.B. 1115, Calabar

Nigeria, West Africa

drgreg.onah@yahoo.com 